\title{
Revisiting Africa's “Socialist” Past to Design Africa's Future Political Economy
}

\author{
Jare Oladosu \\ Department Of Philosophy \\ Obafemi Awolowo University \\ Ile-Ife, Nigeria \\ Jare2dosu@Yahoo.Com
}

DOI: $\underline{\text { http://dx.doi.org/10.4314/tp.v6i1.4 }}$

Thought and Practice: A Journal of the Philosophical Association of Kenya (PAK)

New Series, Vol.6 No.1, June 2014, pp.25-47

thoughtandpractice@gmail.com

http://ajol.info/index.php/tp/index

ISSN: 2076-7714 


\begin{abstract}
The sad reality of Africa's socio-economic underdevelopment is beyond contention. What has been vigorously debated is the choice of a suitable political economy to lift Africa out of this historical abyss. Some have prescribed the adoption of capitalism, i.e. the free market economy. Others advocate for socialism or a centrally planned economic model. Indeed, some African thinkers, especially those of the independence era, contend that some variant of the socialist creed is indigenous to the African economic culture. Yet others have advocated some form of mixed economy, one that would synthesize elements of the capitalist system with elements of scientific socialism. In this paper, we first interrogate the idea of "African socialism". We contend that those who promote this idea operate based on a flawed interpretation of the economic arrangement of pre-colonial African societies. We then propose the adoption of a mixed economy whose content is in part composed of two ideas derivable from a critical evaluation of the pre-colonial political economy of many African societies, namely, the land tenure system and what we describe here as a socialized public sphere.
\end{abstract}

\title{
Key Words
}

African socialism, political economy

\section{Introduction}

The globalization train has taken off. The main actors are the nations of the west led by the United States and the established industrial democracies of Western Europe. The following are among the distinct characteristics of globalization:

1. In the battle of socio-economic ideologies, capitalism has posted a definitive victory over socialism.

2. the pervasive influence of western cultural imperialism. 
3. the resumption, in deed and in word, by the guardians of western civilization, of their self-appointed mission of civilizing mankind; this time around, to spread far and wide the evangelism of democracy and the presumed attendant fidelity to the sanctity of human rights ${ }^{1}$.

No doubt, the conceptual anchor for all the other elements of globalization is the belief in the triumph of "democratic capitalism" over "totalitarian socialism". Many put the moment of that ideological victory to the end of the cold war, symbolized by the fall of the Berlin Wall, the reunification of Germany under a liberal capitalist socio-political regime, the implosion and eventual disintegration of the Soviet Socialist empire, and the reassertion of the political sovereignty of the nations hitherto co-opted into the Soviet empire.

According to Francis Fukuyama, "the triumph of the West, of the western idea, is evident first of all in the total exhaustion of viable systematic alternatives to western liberalism" (Fukuyama 1989, 1) $)^{2}$. Fukuyama sees the manifestation of the triumph of the western idea everywhere:

[it is]in the ineluctable spread of consumerist western culture in such diverse contexts as the peasants' markets and color television sets now omnipresent throughout China, the cooperative restaurants and clothing stores opened in the past year in Moscow, the Beethoven piped into Japanese department stores, and the rock music enjoyed alike in Prague, Rangoon, and Tehran(Fukuyama 1989, 1).

This, Fukuyama concludes, may indicate that we have reached "the end of history as such: that is, the end point of mankind's ideological evolution and the universalization of western liberal democracy as the final form of human government" (Fukuyama 1989, 1).

- For helpful comments on an earlier draft of this essay, I thank Dr. Uwasomba of the Department of English and Dr. Famakinwa of the Department of Philosophy, Obafemi Awolowo University, Ile-Ife. I also thank the peer reviewers of the journal.

\footnotetext{
${ }^{1}$ This trend is evident in several interventions (some brazenly undertaken with the express objective of effecting regime change, others more covertly) in the internal affairs of a growing list of sovereign nation-states, all in the name of humanitarianism.

2 Since its publication in the summer of 1989, Fukuyama's essay has provoked a torrent of critical commentaries. For an early rejoinder to his critics, see Fukuyama's article, "'The End of History?" Debate', in
} Dialogue, No. 89 (March, 1990). For a more comprehensive elaboration of Fukuyama's ideas, see his book, The End of History and the Last Man, New York: The Free Press, 1992. 
As the descendants of western civilization celebrate the ultimate supremacy of their ideology and culture, Africans cannot join in this victory parade. If anything, these times call for serious reflection on the African scheme of things. What is Africa's place in this new globalized order? What fate awaits African descendants, if they are compelled to participate in the current world political economy based on rules crafted by the theoretical custodians of the dominant civilization?

Assuming Africans cannot change the rules altogether, can they at least modify them to lessen the impact of the rushing currents of the almighty global market economy? According to a Yoruba adage, $a$ i se deede araye ni $i$ muni ranti araorun ("frustration with the inadequacies and failures of the present often breeds nostalgia about the past"). Since the accounts of the present in many parts of Africa are but records of serial failures of developmental efforts, we must inquire into whether there are useful insights to be derived in this regard from aspects of pre-colonial political economy. Specifically, we wish to critically examine the elements of the fabled "African socialism", to separate the reality from the myths and fantasies. The point is to see whether we may uncover some features of that traditional socio-economic system that could be adapted to construct a political economy suitable to meet the challenges of contemporary times.

The remainder of the essay is in four parts. In part two, we present an exposition of the salient features of "African socialism", as its proponents conceive it. In part three, we subject this defense of "African socialism" to critical examination. In part four, we argue for the adoption of some form of mixed economy for $21^{\text {st }}$ century African nation-states, adapting as vital components of the system elements of the pre-colonial political economy of traditional African societies. Part five presents our finding and conclusions.

\section{The Idea of "African Socialism"}

Though the sun seems to have set on the idea for now, "African socialism" has had its glorious days. Once it was the unquestioned article of ideological faith among African nationalists and liberation fighters as well as post-independence "progressive" intellectuals. To some of its more fanatical defenders, African socialism as a socio-political creed was simply unassailable. However, the euphoric embrace of African socialism has waned 
considerably, even among the old ideological warriors some of whom, having left it all on the battle field, have since settled down in retirement to what they, in their fighting days, might have considered bourgeois opulence.

But why was African socialism so popular in the era of nationalist struggle and during the first two decades after independence? What are the salient elements of African socialism? What arguments have been adduced in defense of the idea?

Richard Sklar points out that "in African social thought, capitalism and socialism coexist as binary concepts implanted during the era of colonial rule and anti-colonial struggle" (Sklar 1988 , 4). Some have taken the two ideologies to be not only jointly exhaustive of the field of possible political economies, but also to be mutually exclusive. Thus, the near universal endorsement of the socialist creed by the pioneer political thinkers was inversely proportional to their universal rejection of capitalism. One way to appreciate the beauty of the socialist doctrine in the African eye is to consider why capitalism looked so ugly from the point of view of the African freedom fighters.

The inherent dysfunctions of the capitalist system are well known. Capitalism's multitude of defects include the commoditization and attendant exploitation of human labor, hypermaterialism, conspicuous consumption and waste in a world where many have nothing, environmental degradation, and chronically unequal distribution of wealth leading to the concentration of enormous amounts of wealth in a few hands often translating into the concentration of political influence and power in the same few hands, which, of course, is anathema to the spirit of democratic egalitarianism. Sklar observes that "in Africa... capitalism has been associated with the humbling experience of alien domination"(Sklar 1988, 1).

According to Leopold Senghor, capitalism not only inspired colonialism, but also provided the impetus for the enslavement of Africans by the colonizing Europeans, and the transatlantic slave trade (Senghor 1998, 442). After all, you can colonize a people without also enslaving them; and surely you can colonize and enslave a people without also uprooting the productive segment of their population, the young and the able-bodied ones. The dynamics of the capitalist political economy produced that triple whamming for Africa, precipitating a socioeconomic dislocation of no mean proportion. The catalyst for European colonialism in Africa and its attendant evils was capitalism's insatiable need for cheap labor 


\section{Jare Oladosu}

required in the production of goods and services and ready markets in which to dump its products.

Having determined that capitalism is an evil ideology, an avid facilitator of racial oppression without any redeeming features whatsoever, pioneer African political thinkers were unanimous in endorsing socialism. However, what they embraced was not the orthodox western variety of the socialist creed that Julius Nyerere labeled "doctrinaire socialism" (Nyerere 1968, 11). Instead, what they espoused was "African socialism", or, as Leopold Senghor liked to characterize it, "the African mode of socialism" (Senghor 1998, 442). This was a socialism indigenous to the African civilization. Therefore, in designing an appropriate political economy for the post-independence African nation-states, all that was required was to take a mental trip back into the annals of African pre-colonial socio-economic system, dig up the communal socialism characteristic of its culture, dust it up and rebrand it for the contemporary age. What then are the salient elements of this African (communal) socialism? How was it to be rebranded to suit modern realities?

As Julius Nyerere argues in Ujamaa, the existence of African socialism is indicated by three salient elements. The first is communal ownership of the single most important means of production, land (Nyerere 1968, 7). In a predominantly agrarian economy, such as prevailed in many parts of pre-colonial Africa, there can be no overemphasizing the importance and sacredness of land. "Land" in this context is a generic concept. It includes land designated for building purposes, that is, for the construction of shelters, markets, shrines, etc.; it also includes arable land, that is, land for cultivation of crops, fishing ground, grazing fields, mining pits, and even the impenetrable forest. All of these categories of land were communally owned: vast tracks were owned by lineages and clans. The idea of individual ownership of any track of land was foreign to African culture. Kings, chiefs and lineage heads held such lands in trust on behalf not only of their living subjects or lineage members, but also on behalf of their ancestors, future generations, and, ultimately, for the gods.

Under this land tenure system, individual users of land were allotted plots of land (upon application) by their lineage or clan head or chief, as the case may be. The use (never the ownership) of such portions of land may pass from father to son down the generation line, but the land reverted to the pool of communal holding upon cessation of use or upon revocation of allotment. 
Secondly, according to Nyerere, in traditional African society, there was total absence of exploitation of labor of one person by another. The class of economic parasites, either in the form of the capitalist exploiter or the lowly urban idler - both products of the capitalist system - was nonexistent (Nyerere 1968, 5). When Nyerere declared that in traditional African society everybody was a worker, he meant that everyone in that society had to work to earn his or her keep, with the understandable exception of the very young, the very old, and the severely disabled. The dignity of work was an integral aspect of the positive morality of the traditional African society.

For Nyerere, the third element of African socialism derives from the first two. With everybody having equal access to the most basic means of production, land, and in the context of a social order where everyone has to engage in some form of productive activity, traditional African socialist society was a classless society (Nyerere 1968, 11). The society was populated by persons all of whom must mix their productive labor with the endowments of nature, principal among which is land, using the tools they fashion, to secure the resources they required for their sustenance and comfort. It is not surprising that the traditional African socialist system placed a near absolute premium on the sharing of resources, whether raw natural endowment, land, water, or resources obtained from men's productive exertions. Nyerere suggests that this attitude of sharing and caring was indispensable to African socialism. For Nyerere, socialism is essentially distributive (Nyerere 1968, 4).

Other features of traditional African socialism were said to be derivable from the foregoing. We consider just two. First, there being no clearly recognizable socioeconomic classes in traditional African societies, African socialism, unlike the orthodox western variety, was not heralded by class antagonism or conflict. African socialism was the product of a peaceful natural evolution, not the outcome of a violent revolution (Nyerere 1968, 11-12). Second, because as J.S. Mbiti has famously reported, Africans essentially live in a religious universe (Mbiti 1969, 62), tribal or communal African socialism was robustly theistic. The wide scope of the traditional African community extends back and forth in time to include not just the living members of the society but also the departed ancestors, the unborn generations, and the unseen spirits and deities. Ancestors have to be placated to avoid their wrath and secure their blessings.

To transit from traditional African socialism to a modern African socialist system, these elements of communal socialism would be adapted to the objective conditions of the modern, 
post-independence African society. We find two classical attempts at such adaptation in the political manifesto of the Tanganyika African National Union (TANU). Two cardinal provisions in The Arusha Declaration, the blue print for socialism in Tanzania, are the insistence on communal ownership of land, whereby the land would be held in trust by the government on behalf of Tanzanians, hence preserving the essential distributive import of traditional African socialism (Nyerere 1968, 13-37).

Modern African socialism would guarantee both economic democracy and spiritual freedom. It would borrow from the European variant Europe's scientific and technical competencies, most especially, Europe's spirit of technological progress. These, Senghor proposes, "would be grafted like scions on the wild stock of Negritude" (Senghor 1998, 443). "Negritude" is defined as "the whole complex of civilized values; cultural, economic, social and political which characterize the black people" (Senghor 1998, 440).

The economy of the modern African state under the socialist creed would, invariably, have to be centrally planned. In some cases, such as in Senghor's Senegal, the regime of central planning would be combined with active solicitation for private capital and foreign investment. In other places, such as Nyerere's Tanzania, although suitable foreign investment and injection of private capital would not be discouraged, the emphasis would be on selfreliance.

\section{“African Socialism” a Case of Mistaken Identity}

The thesis that some form of socialism is indigenous to the African civilization and that to reinstitute the socialist ideology in modern, post-independence African nation-states is merely to "reclaim an African socioeconomic identity" is historically and intellectually questionable. After all, socialism is not a genetic material which the present generation of Africans could have inherited, through the blood line, from their ancestors. Not surprisingly, the thesis and the arguments offered in its defense have been critically reexamined by African and non-African social and political thinkers. ${ }^{3}$ Perhaps the most comprehensive critique of

\footnotetext{
${ }^{3}$ On this, see the collection of essays in William H. Friedland and Carl G. Rosberg, jr. (eds.), African Socialism, Stanford University Press, 1964; Fenner Brockway, African Socialism, London: The Budley Head; Bismarck U.
} 
the thesis is to be found in Kwame Gyekye's writings. Gyekye's philosophical assault on the idea of African socialism is systematic and unrelenting. ${ }^{4}$

For Gyekye, examined from any angle, the thesis of a primordial African socialism crumbles (Gyekye 1997, 144-170). After a careful review of the arguments for the thesis, Gyekye concludes: "the view of the traditional moorings of the modern socialist ideology in Africa presents a simple and misguided picture of an otherwise complex situation" (Gyekye 1997, 149). What prevailed in some pre-colonial African societies was tribal communalism or tribal communism. According to Gyekye, Africa's independence political leaders and those inspired by their liberationist campaigns committed a logical blunder in identifying tribal communalism as a form of socialism. "The alleged relation of identity between the two systems can logically be denied," Gyekye argues, "on the grounds that not everything that can be asserted of communalism can be asserted of socialism, and vice-versa" (Gyekye 1997, 148). He contends that communalism "is essentially a socio-ethical doctrine, not particularly, economic..." (Gyekye 1997, 148). Socialism, on the other hand, "is fundamentally economic, concerned, as a matter of testament with the relations or modes of production" (Gyekye 1997, 148). Specifically, "[it] is an economic arrangement involving the public control of all the dynamics of the economy" (Gyekye 1997,148), that is, the processes involved in the production and distribution of goods and services. Indeed, not only are tribal communalism and socialism not identical, there is no necessary or logical connection between them, even though they may have certain characteristics in common. In light of this conceptual separability, it is possible to conceive one of these ideas or systems without the other.

Mwansasu and Cranford Pratt (eds.), Towards Socialism in Tanzania, Toronto: Univ. of Toronto Press, 1979; Walter A. E. Skurnik, "Leopold Senghor and African Socialism”, Journal of Modern African Studies, Vol. 3, No. 3 (Oct, 1965), pp. 349 - 369; Onigu, Otite (ed.), Themes in African Social and Political Thought, Enugu, 1978; M. Akin Makinde, “Awolowo and African Socialism: A Philosophical Study”, in M. Akin Makinde, African Philosophy the Demise of a Controversy, Ile-Ife: Obafemi Awolowo Univ. Press, 2007, pp. 184 - 205.

${ }^{4}$ On this, see Gyekye, Kwame. Tradition and Modernity: Philosophical Reflections on the African Experience, Oxford: Oxford University Press, 1997, especially chapter 5. See also, Gyekye, Kwame. The Unexamined Life: Philosophy and the African Experience (an inaugural lecture delivered at the University of Ghana on May 7, 1987), Accra: Sankofa Publishing Co.Ltd., 1996; and Gyekye, Kwame. African Cultural Values: An Introduction, Accra: Sankofa Publishing Co., 1996, especially chapter 6. 


\section{Jare Oladosu}

It can thus be demonstrated that what independence political leaders labeled as African socialism was not. This we can do by taking a closer look at what they themselves present as the historical evidence for the existence of the African brand of socialism. Let us consider two of the suggested elements of African socialism, namely, the land tenure system, and the supposed non-existence of socioeconomic classes. There is every indication that the African socialists' account of the traditional land tenure system in many parts of Africa is accurate. Ownership in perpetuity of all land was vested in the community; provisions were made for the individual's use of land by the designated authorities, from the communal holdings. Nevertheless, this has never been the land tenure system under any known form of socialism. Fundamentally, socialism is the political economy wherein all the aspects of a society's economic life are centrally planned and executed. In a socialist system, not only is land communally owned, it is also communally used, in the sense that all aspects of the economy are centrally organized.

Under the traditional African land tenure system, on the other hand, though land was owned by the community, once a portion of it was allotted to an individual, his or her use of it was strictly private. The production of goods and services in pre-colonial Africa was primarily privately organized. That was so, notwithstanding the legendary African spirit of sharing and caring for others. Even members of a nuclear family would, at some point, demarcate the boundaries of each individual's farm plots. For example, among the Yoruba of south-western Nigeria, upon reaching adulthood, a male child is assisted to find a wife, after which he is allotted his own portion of the lineage land to farm. The symbolic demarcation of a boy's farm plots from his father's (oko yiya) is the culmination of the rites of passage from boyhood to manhood. It is at this stage that the Yoruba would say oko kii je ti baba tomo ki omo ni aala ("the joint ownership of a farm land between a father and son does not mean that each would not know the boundary of his own plots"). At this stage in a young man's life, what he is being told is that henceforth he should take full responsibility for his and his family's economic destiny. The phenomenon of centrally planned economies in pre-colonial Africa has not been recorded by historians or anthropologists.

The second suggested evidence of communal socialism in pre-colonial Africa, namely, the non-existence of socio-economic classes, is even more controversial. It is not clear how far back in time one has to go to find a predominant number of African societies that would fit the profile in the contemplation of this characteristic: a society, small in population, enjoying 
demographic homogeneity, with a simple agrarian economy. Having found such a simple social order, it is not clear how to gauge the degree of its relevance to contemporary realities. Surely, by the commencement of European colonialism, many African societies had advanced way beyond that simple, possibly primitive stage. Empires and kingdoms had existed for centuries in pre-colonial Africa, and these complex political formations could not have been founded on simple agrarian communalism.

An indispensable feature of empire-building is urbanization. Urbanization predated colonialism in many parts of Africa. With urbanization comes occupational specialization and professionalization. Many professions had developed in pre-colonial Africa. There were professional engineers (the black smiths), professional artists, wood carvers, leather decorators, textile workers, professional entertainers, drummers, singers, poets, professional soldiers (esos among the Yoruba), professional hunters, farmers, health care professionals, medicine men, herbalists, diviners, and various cadres of civil servants from the court linguist to the town crier. Among the predictable effects of occupational specialization and professionalization are disparities in income and social standing, signaling the emergence of socio-economic hierarchies. There is no reason to suppose that the situation was any different in pre-colonial Africa. To describe as classless a society in which there were clearly identifiable socioeconomic hierarchies in the population is to play a game of semantic hideand-seek. ${ }^{5}$

Perhaps the stipulation is to restrict the designation of the concept of a socio-economic class to the two antagonistic classes produced by $19^{\text {th }}$ and $20^{\text {th }}$ century industrial capitalism, viz, proletariat and bourgeoisie. We reject that conceptual proposal. There is no compelling logical or practical reason to restrict the meaning of the concept "class". We take note that Karl Marx and Fredrick Engels would not endorse the proposal either, given the memorable opening sentence in their Communist Manifest: "the history of all hitherto existing society is the history of class struggles" (Marx and Engels 1968). We believe, however, that Marx and Engels err in thinking that wherever there are socio-economic classes there must be class

\footnotetext{
${ }^{5}$ We find President Senghor playing such a game when he admonishes that being classless should not be confused with being without hierarchy. "Classlessness in this context", Senghor claims, "only means being[a] community-based society in which hierarchy and therefore power is founded on spiritual and democratic values" ( Senghor, "Negritude and African Socialism”, op.cit., p. 443). Pray, what could that possibly mean?
} 


\section{Jare Oladosu}

warfare. Julius Nyerere, on the other hand, errs in thinking that the absence of class warfare means the absence of socioeconomic classes. Marx and Engels incorrectly assumed that where there are socio-economic classes substantial forms of injustice must prevail. John Rawls's seminal contribution to social and political thought is his argument to the effect that inequality need not always be symptomatic of injustice (Rawls 1971, chap. 2).

It is noteworthy that slavery and other allied practices were already known to many parts of Africa long before the Arabs and later the Europeans brought their own respective forms of slavery to the continent. We find ample linguistic evidence and historical records of these practices all over Africa. The Yoruba language differentiates between a slave (eru) and an indentured servant (iwofa). The legal relationship between the slave and his or her owner was that of a piece of property to its owner. The indentured servant, on the other hand, was never to be confused with the master's property. He or she would be at the master's place, working for the master, pending the repayment of a loan taken by the servant's family. Practices such as slave-owning and indentured servant holding provide evidence that Nyerere's belief in classless pre-colonial African societies is illusionary. Such practices underscore the disparities in wealth, privileges and life prospects within the limited opportunities available for the manifestation of such experiences in that "ancient" order. History also records largescale transnational and trans-regional commerce in pre-colonial Africa. For example, the huge volume and wide geographical spread of the trans-Saharan trade has been well documented. However, there is no shred of evidence that those transnational merchants were tribal socialists, nor that the proceeds from their commercial activities were remitted into some communal treasury.

In sum, we believe Gyekye is correct in concluding that by completely discountenancing the acquisitive individualism exhibited by pre-colonial African societies, Africa's independence political theorists fundamentally misunderstood the traditional political economy (Gyekye 1997, 162). A more accurate interpretation of the available records on the economic life of many pre-colonial African societies would suggest that elements of capitalism and socialism had long been incorporated into their political economies. As Richard Sklar has observed, "each [of capitalism and socialism] can be reconciled with a partial selection of pre-colonial African economic practices and systems of belief ..." (Sklar 1988, 4). Kwame Gyekye agrees that "capitalism was already a palpable feature of the pre-colonial system of economic management ...", and that "what will be more correct to say ...is that the traditional 
economic culture exhibited features of both the 'socialist' and capitalist methods in the management of the economic lives of the people" (Gyekye 1997, 157).

\section{Some Elements of a Mixed Economic model for Africa}

If we take a quick stock of the discussion thus far, two conclusions would emerge: first, that not only are tribal communalism and scientific socialism not identical, they are not even logically equivalent. As we have argued above, following Gyekye's lead, there is no necessary or conceptual connection between the two ideas. Thus, the fact that they tend to have certain characteristics in common, for example, a humanistic orientation, is purely contingent. Second, many societies in pre-colonial Africa were at developmental stages far beyond the tribal communalist level. These, no doubt, are interesting conclusions, but they are hardly ground breaking. To terminate our reflections on this note would be to fail to draw the most valuable lessons derivable from our analyses. In any case, it would leave unanswered the fundamental question: what ideological path would be most promising for the $21^{\text {st }}$ century African societies? Our contention is that the foregoing analyses should yield useful insights into how to answer that question.

Consider the following. If there existed whole hierarchies of socio-economic classes in many pre-colonial African societies, why was there a virtual absence of class antagonism? Why were pre-colonial Africans able to blend the individualistic acquisitiveness characteristic of the capitalist creed with an iconic degree of humanism? Was it a function of their innate goodness ${ }^{6}$ or were there certain objective conditions that facilitated the humaneness in the traditional African "capitalist”? Our pre-colonial ancestors, it would seem, operated more like "capitalists" at the level of the production of goods and services, but behaved more like "socialists" at the point of distribution. Blending these seemingly incompatible ideological

\footnotetext{
${ }^{6}$ Leopold Senghor came very close to making such a claim. He narrated how the evils of racial hatred was forcefully demonstrated to himself and his associates in the liberation movement by the atrocities committed by the Nazis during their reign in Germany, and how that experience purged him and his associates of the "antiracist racialism" characteristic of the first stage in the evolution of the social/political philosophy of Negritude: "such hatred", Senghor lamented, "such violence, ah! Above all, such weeping and such shedding of blood produced a feeling of revulsion - it was so foreign to our continent's genius - our need to love" (Senghor, "Negritude and African Socialism", op. cit. p.440. Emphasis is mine).
} 
sentiments is often thought to be problematic, if not altogether impossible. How were the Africans of those days able to do it?

No doubt, dwelling in close proximity to persons one was related to or otherwise closely associated with was an important factor in the pervasive display of altruism by pre-colonial Africans. It is difficult to be uncaring about other people's needs and circumstances with all familiar eyes on one. That would be like attempting to do evil in the full glare of daylight. Did we not just report above that a significant level of urbanization had taken place in those pre-colonial times? How come people had to live close to their kith and kin? The fact is that pre-colonial African towns and cities were laid out in sections, quarters and compounds. Lineages established their compounds at different quarters in the town or city. To further facilitate intra and inter lineage identification, there was the practice of facial marks incision in some traditional African societies. Although the practice has all but ceased, one can still find today elderly persons in ancient towns and cities, like Oyo, Ede, Ogbomosho, Saki, all in southwestern Nigeria, who only need to look at the facial marks on a person's face to tell, with uncanny accuracy, what part of town the person is from.

What then prevailed at that time was urbanization without the shrouding veil of anonymity. In that kind of social environment, enlightened self-interest would counsel a healthy dose of altruism. A crass display of selfishness would mark one out as a moral cretin and create a social pariah of the individual. In extreme cases, such antisocial behavior might provoke severe reactions from the community. Africans in traditional times were thus socialized to recognize that it was in their self-interest to be caring, and to acknowledge the humanity in all men and women. Individuals in that social milieu were taught to appreciate the need to build a sizeable equity of goodwill with their fellow men and women, not only as a form of insurance against severe economic times, but to remain in good social standing even in times of plenty. As a Yoruba proverb sums it up, a ki i lahun kaniyi ("being held in high social esteem is beyond the dreams of a miserly person").

The second major factor that explains the absence of class antagonism in pre-colonial African societies is the fact that opportunities to display class and wealth differentials were very limited. There was only so much one could acquire and flaunt. ${ }^{7}$ There being no automobiles

\footnotetext{
7. According to Chief Obafemi Awolowo, the situation that prevailed in Africa in the olden days presented "insufferable physical obstacles" to the tendency to acquire much wealth. "In the absence of portable and
} 
or the technology to build skyscrapers in those days, at best a wealthy individual would acquire horses or other kinds of animals for transportation, build a sprawling thatched-roofed house, and fill his compound with wives, children, slaves and servants. Such possessions were, of course, nothing compared to the limitless opportunities that exist nowadays to display superiority in wealth and social class. Clearly, the distance between a person on a horse and a pedestrian is much closer than the distance between someone flying in a private jet and a pedestrian.

It may be true that modern technology now "makes kingly luxuries [of times past] common places for large numbers of people" (Hartshorne 1974, 69-74). It is equally undeniable that modern technology has facilitated the creation of a vast array of ultra-luxury goods and services for the exclusive consumption of today's capitalist princes and princesses. Suppose a wealthy individual in pre-colonial Africa were to desire to take a vacation: where might he or she go, and what sort of services might he or she hope to enjoy there?

Perhaps the most important factor which produced the happy mix of ideological temperament in pre-colonial Africa was the communal ownership of land. Although individuals enjoyed a wide degree of liberty to utilize the portion of the communal land allotted to them, all such persons ever had was possession for use, never ownership of any sort. There was always a lingering awareness that every member of the community, including the least endowed, were joint owners of the land - all were share holders in the common patrimony. That awareness did at least two things. On the one hand, it made wealthy individuals temper the feeling of superiority, which usually accompanies wealth, with some modesty. Even for the very wealthy, continued enjoyment of the use of the communal land, for whatever purpose, depended on behavior in conformity with the basic rules and ethical norms of the society. The communal land was always there for an individual to return to when all else had failed. Having failed at some venture or the other in the city, one could always go back to the village to work a portion of the land. Prolonged unemployment and urban destitution were therefore virtually unknown to pre-colonial Africans. greed to accumulate the things of this world were reduced to the barest minimum" Obafemi Awolowo, The People's Republic, Ibadan: Oxford Univ. Press, 1968, p. 209, quoted in M. Akin. Makinde, African Philosophy: the Demise of a Controversy, Ile-Ife: Obafemi Awolowo University Press, 2007,p. 190 
We have held throughout this paper that the choice of a system of political economy for postcolonial African states was initially thought to be narrowed down to capitalism or socialism, a binary belief system, according to which capitalism and socialism are mutually exclusive and jointly exhaustive of the ideological possibilities. This, according to Sklar, "is not conducive to innovative advances in social theory and organization" (Sklar 1988, 4). The theoretical inadequacy and practical disutility of this binary belief, vis-à-vis the aspirations of modern African nation-states, has become all the more glaring in the light of contemporary developments. It would be foolhardy for African states to opt for "straight socialism" in the undiluted form (Gyekye 1997, 145). Most of the countries in other parts of the world are retreating from that ideological path. Maybe there is something in the human nature, after all, that renders that form of socialism "unworkable". Maybe greed, the psychological agent that catalyses capitalism's prodigious levels of productivity, ${ }^{8}$ is, as has been suggested, as inescapable and as unalterable as gravity. ${ }^{9}$

It would equally not be advisable for African states to leap into an unmodified capitalist arrangement. Africans cannot afford to surrender their destinies into the proverbial invisible hands of the so-called global market forces. Market forces do not serve the goal of social equity. A wholesale leap into the global market system by African states would be akin to economic suicide by exposure to the rapid currents of globalization. In this light, the advocates of "Africapitalism"10 would do well to reconsider the content of their prayer. What they seem to advocate is the wholesale delivery of the African economy into the hands of private capital, which in turn is in the vice-like stranglehold of global market forces. If the first generation of Africa's political thinkers worried about what capitalism did to Africa in the past, the present generation would do well to worry about what untamed capitalism would do to Africa in the present and future. Sam Aluko has cautioned that the dogmatic eulogy of

\footnotetext{
${ }^{8}$ Kwame Gyekye describes capitalism as "the system that historically has been most successful in the creation of wealth, fundamental to the fulfillment of human needs and well-being" (Gyekye, Tradition and Modernity, op.cit., p. 159).

9 . According to William Niskanen, "blaming financial crisis on greed... is like blaming airplane crashes on gravity. Greed and gravity are always with us, and capitalist markets usually channel self-interest into mutually beneficial behavior"( William A. Niskanen, "The Undemanding Ethics of Capitalism”, Cato Journal, Vol. 29, No. 3 (Fall, 2009), P.559)

10 "Africapitalism" is an idea that Tony Elumelu and his associates have been promoting vigorously. See the Tony Elumelu Foundation's document entitled “Afrocapitalism: The Path to Economic Prosperity and Social Wealth" on the internet. See also an interview with Elumelu in the New African magazine, issue 528 of May 2013, at p. 50
} 
the market is a new form of exploitation by the Western economies. Africa today is virtually not part of the market. The African economists should, therefore, not be part of those who eulogise that market(Aluko 2007, 79-114, at 94). ${ }^{11}$

Since neither orthodox socialism nor unmodified capitalism would put Africa in good stead, some form of mixed economic arrangement becomes inevitable. The problem has always been to specify the content of such a system. We conclude this essay by highlighting two elements of the socio-economic life of pre-colonial African societies that could form essential components of a mixed political economy for $21^{\text {st }}$ century Africa.

The first is the land tenure system. My proposal is that land, as widely conceived above, should be communally owned. Trusteeship of land should then be vested, as appropriate, in the central, regional, state, local or municipal government. Legal and social frameworks for the granting of land should be designed, depending on the form in which the land is in and the use to which it would be put. These may range from short or long-term leases to concessionary arrangements. Howsoever such details are determined, certain fundamental principles would have to be upheld. First, the idea of a person, whether a natural or corporate person, owning a portion of our land in perpetuity would be outlawed. The ancestors of today's Africans would find the idea of an individual being the sole owner of a mining quarry, an oil well, or an entire Island, an unconscionable outrage. The present generation of Africans should not be comfortable with such manifestations of the excesses of the capitalist system either. Second, circumstances that could result in the forfeiture of a grant of land would be expressly stated in the terms of the grants. These may include conduct that transgresses the basic laws and moral requirements of the society in particularly egregious manners, such as the use of the land as a base for criminal activities, massive environmental degradation resulting from the use of land, etc. Third, every African, so recognized under the law of the relevant society, should have some where he or she can return to, to ask to be allotted a piece of land to "cultivate". To this end, the practice of indigenship currently obtaining in many parts of Africa may require comprehensive reviews.

\footnotetext{
${ }^{11}$ To underscore Aluko's point, it is a distressing irony how some economic and social commentators have tended to celebrate the fact that Africa was virtually untouched by the global economic meltdown that has been ravaging many of the developed economies of North America and Europe, from the last quarter of 2008. Far from being a matter for rejoice, what this phenomenon demonstrates is the truth of the time-honored cliché: those who are down need fear no fall. Or, that only the living can die. If Africa has not gone down with the global market it is because Africa was not in the market to begin with.
} 


\section{Jare Oladosu}

We are not oblivious of the fact that there may already be laws in place in some African countries with provisions for land tenure arrangements similar to my proposal. In Nigeria, the Land Use Decree No. 6, of 1978 (now Land Use Act) purports to vest ownership of land in the people. Governments at the different levels are to serve as trustees in respect of such lands. We have proceeded in the last paragraph without much allusion to this law for two reasons. One, our conception of "land" may be wider than what is contemplated in law. Two, and perhaps more pertinent, law might as well not be in existence. Where there are adequate legal provisions to implement aspects of the proposal on land tenure above, the laws should be diligently enforced. Where, as in Nigeria, the law itself seems to be fundamentally defective, there would be the need to fix the flaws in the law. ${ }^{12}$

The second feature of the socio-economic life of pre-colonial African societies that we consider highly desirable in post-colonial African states is the limited opportunity that existed to flaunt wealth and class superiority. Compared to traditional Africa, the reality of contemporary life testifies to the existence of limitless opportunities to engage in conspicuous consumption by way of indulgencies in ultra-luxury goods and services. This reality cannot be wished away; indeed the frontiers of such indulgencies are expanding daily. However, we can mitigate the pernicious effects of this reality by adopting social policies aimed at socializing the public sphere.

As a matter of national policy, our public officials, from the President to the messenger at the municipal office, should be required, by law, to patronize public services and institutions. In this regard, two essential services and the institutions that provide them come readily to mind, namely, health and education. It is instructive that the excesses and insensitivity of many of our public officials, especially those in the top echelons of the public service, are manifested in their privileged access to high quality educational and health services, usually obtainable either in the private sector or, better still, outside our shores. It is a well-known fact that our top public servants do not rely on the available public health and educational institutions for which they formulate policies to serve the public sphere. These practices shortchange the citizens of African nations in several respects.

\footnotetext{
12 . For incisive comments on some aspects of the Land Use Act, see, L.K. Agbosu, "The Land Use Act and the State of Nigerian Land Law”, Journal of African Law, Vol. 32, No. 1 (Spring, 1988), pp. 1 - 43
} 
To begin with, public officials can afford to neglect our public institutions without having to worry about the consequences of such neglect for themselves, their families and close associates, who could be sent off to access high quality services elsewhere. Secondly, these practices constitute huge drains on African economies, because the funds to pay for elites' taste for foreign goods and services invariably come from the public treasury. Whether it is a ministerial medical trip abroad or a presidential ward enrolled in an elite educational institution abroad, the public always gets to pay for it. Thirdly, these practices also fuel official corruption. Top government officials would do anything to acquire the resources to satisfy their expensive tastes while in office and to sustain their lavish life styles after they leave office. As a result, they inflate the costs of contracts for public procurement to meet these personal expenses.

By socializing the public sphere, we could be reasonably sure that public officials who have the responsibility to maintain our public institutions would be fully committed to the quality of those institutions, since they too would have a stake in the well-being of those institutions. These socializing measures will also minimize, as far as public officials are concerned, the opportunity for the unethical display of ostentation at the expense of the general public. Other measures to be adopted may include prohibiting public officials from operating foreign bank accounts and going on vacation abroad while in office. Those who aspire to serve us, at whatever level, must be willing to take us as we are, or more accurately, as they make us.

It is worthy of note that none of the measures we are proposing for socializing the public sphere are entirely new or revolutionary. There are indications that some African countries at least pretend to subscribe to some of these measures already. We acknowledged the existence of the Land Use Act in Nigeria, for example. Again, it is unlawful for a Nigerian public official to operate a foreign bank account. However, here, as in the case of the Land Use Act, the law exists, for all practical purposes, only on paper.

Some might object to the adoption of these measures on several grounds. One could be that the adoption of such "restrictive" measures could discourage talented individuals from undertaking public service. Another ground could be that the measures would do very little to reduce the display of class superiority through the flaunting of wealth. After all, the superior quality goods and services would still be available in the society anyway, to be enjoyed by those who are not public servants. Might a public official not wait to enjoy those high quality services after his or her stint in public service? Others could point out that in the light of the 


\section{Jare Oladosu}

political dispensation in many African states today, the chances of passing and enforcing the legislation sufficiently potent to institute these proposals for socializing the public sphere are pretty slim. Nevertheless, we must not give up. We may in turn defend these proposals as hereunder.

First, the opposition to our proposal underestimates the gratification derivable from occupying high public offices. Many talented individuals in the developed democracies of the west serve their nations in public offices at considerable personal loss and inconvenience. There is nothing to suggest that Africans are so differently constituted such that they should experience a severe shortage of talent to serve in public offices, just because we require public office holders to patronize the services they help to provide. The objection seems to assume that the proposal to socialize the public sphere is borne out of some sadistic intent to drag everybody down. On the contrary, it is informed by the desire to lift everybody up. The idea is not to force some people to have less, but rather to make the benefits accruing from public service spread to larger portions of society.

The second objection presents a strong argument. There is nothing we can do to take us back to the pre-colonial era where wealth and class could be exhibited only to a limited extent. Nor do we desire such socioeconomic retrogression. As for the suggestion that all that a public official need to do to enjoy high quality services is wait until one is out of public service, we here concede that there is not much we can do to prevent that. Of course, we can assist to accentuate the fun of waiting, by specifying a five-year period of grace after disengagement from public service before one could access such high quality services available in the private sector. However, if one would rather wait until one retires from public office before enjoying one's ill-gotten wealth, for example before enrolling one's children or wards in school, then we can only hope that such a person's waiting would be well worth it.

Finally, the contention that it would be extremely difficult to effectively bring about the socializing of the public sphere, say by passing and vigorously enforcing appropriate legislation in the present dispensation in many African states, is well taken. We must admit that what pass for governments in many of our countries in today's Africa are mere assemblies of self-seeking politicians.

In the operations of modern democracies, the doctrine of the separation of powers, according to which different branches of government (executive, legislative and judiciary) have distinct 
functions and check each other, is being approximated in other places to varying degrees. In many African countries, on the contrary, the so called branches of government function more like the operational arms of an organized crime syndicate. Now, persons who are profiting from the existing order can hardly be relied on to effect radical changes in the system. Nevertheless, these proposals are not, strictly speaking, addressed to the governments of African states. They are instead addressed to fellow Africans, men and women of ideas, who seek a future for Africa. Some day they will rise again to take their destinies in their hands.

\section{Conclusion}

We conclude by reiterating the aim of the constructive component of this essay. Having determined that neither capitalism nor socialism each untamed or unmodified would serve well the interest of modern African societies, the inescapable conclusion is to settle for some form of mixed political economy. The question would be, what ingredients should go into this ideological mix? In answer, what we have done is to propose the inclusion of two elements derivable from a careful analysis of the political economy of some, if not all, precolonial African societies. These are the land tenure system and what we described as a programme for socializing the public sphere, designed to improve the lot of the suffering masses, and to reduce the unsustainable level of disparity between, on the one hand, the economic and political elites, and on the other, the overwhelming majority of the citizens of African states.

Our aim has not been to deliver a fully distilled ideological package. we have operated with the more modest objective of suggesting some of the ingredients that should go into the mix. These measures can be incorporated into the political economy of African states one by one or jointly.

Some might still consider even this modest goal objectionable, because the proposal would be difficult to execute if not altogether unrealistic. We clearly anticipated some of the constraints that could be encountered in the attempt to implement these ideas. Nevertheless, we have also pointed out that the proposals are neither entirely new nor outlandish. we would actually consider untamed capitalism more counterintuitive than what we are proposing. The idea that a single business magnate in Africa would be wealthier than some African nation states or 
several of them put together is, in our view, the height of psychosocial absurdity. Africans of the pre-colonial era would, no doubt, consider such a scenario to be utopian or worse, simply inconceivable. The suggestion implicit in the present argument that the teeming masses of African people who toil under the current oppressive socio-economic order might some day aspire to throw off the yoke and change the system, is, in our view, quite sensible. If someone were to characterize that aspiration or a proposal offered to breathe some life into it as in any way delusory, we would not agree.

Left to its own devices, capitalism has the tendency to degenerate into the evil creed of social Darwinism. Thus we find nations of the west, the epicenter of modern capitalism, devising various welfare schemes to dilute the psychosocial poison of unregulated capitalism. The point in all these welfare programmes is to put a human face on the capitalist monster. Even the self-acclaimed inventors of modern capitalism cannot seem to take it raw. In the final analysis, what we have been proposing here is to put a human face on global capitalism that is African in character and value. 


\section{References}

Aluko, Samuel. 2007. "New Directions on Scholarship in Economics in Africa". In Sola Akinrinade et. al. eds. Rethinking the Humanities in Africa. Ile-Ife: Obafemi Awolowo University.

Fukuyama, Francis. 1989. “The End of History?” The National Interest, No. 18.

Gyekye, Kwame. 1997. Tradition and Modernity. New York: Oxford university press.

Hartshorne, Charles. 1974. "The Environmental Result of Technology”. In William T. Blackstone ed. Philosophy and the Environmental Crisis. Athens: University of Georgia press.

Marx, karl and Frederick Engels. 1968. "Manifesto of the Communist party". In Marx and Engels. Selected Works, vol. 1. Moscow: progress Publishers.

Mbiti, John. 1969. African Religions and Philosophy. New York: Double Day \& Co. Inc.

Nyerere, Julius. 1968. Ujamaa: Essays on Socialism. Dar es Salaam: oxford university press.

Rawls, John. 1971. A Theory of Justice. Cambridge, Mas.: Harvard university press.

Senghor, Leopold. 1998. "Negritude and African Socialism”. In P.H. Coetzee and A.P.J. Roux eds. The African philosophy Reader. London: Routledge.

Sklar, Richard L. 1988. "Beyond Capitalism and Socialism In Africa”. Journal of Modern African Studies, vol. 26 no. 1. 